\title{
Strategi Peningkatan Manajemen Kurikulum dalam Pengembangan Mutu SDM Menuju Terwujudnya Lulusan Madrasah Aliyah Berwawasan Internasional
}

\author{
Djuwarijah $^{*}$
}

\begin{abstract}
Abstrak
The urgent orientation of curriculum management on the context of developing human resources quality especially about out put of education at internasional Islamic senior high school is a effort to achieve four (4) primary competences; academic competence, personal competence, social competence, and spiritual competence. For improving curriculum management in order to develope human resource quality, International Islamic high school has to apply good strategy to reach competitif and qualified its educational out put. Its strategies are: first, strategy based on organization system approach where it stresses to organize curriculum independently, creatively, and innovatively by the Islamic sinior high school. Second, strategy based on purposes focus approach covering several aspects; inquiring sciences, inquiring standart skill standart, inquiring coompetence, character building, and mastering ability for solving social problem of children. Third, strategy based on competence approach focusing on inquiring certain competence based on the development stapes of children. The success of strategies also should be supported by
\end{abstract}

* Penulis adalah dosen tetap Program Studi Pendidikan Agama Islam FIAI UII Yogyakarta

NO. 2. VOL. I. 2008

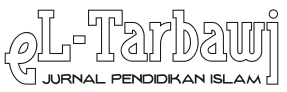


school leader's ability to mobilize resources potentiality that available at school.

Keywords: Curriculum management, strategy, International Islamic Senior High School

\section{A. Pendahuluan}

Dalam era globalisasi dan pasar bebas manusia dihadapkan pada perubahan-perubahan yang tidak menentu. Ibarat nelayan di "lautan lepas" yang dapat menyesatkan jika tidak memiliki "kompas" sebagai pedoman untuk bertindak dan mengarunginya. Hal tersebut telah mengakibatkan hubungan yang tidak linier antara pendidikan dan lapangan kerja atau "one to one relationship", karena apa yang terjadi dalam lapangan kerja sulit diikuti oleh dunia pendidikan, sehingga terjadi kesenjangan. Menanggapi hal tersebut dan crisis moneter yang melanda negara-negara Asia akhir-akhir ini, Direktur Pasipic Economic Cooperation (Tilaar, 2001:21) menyatakan bahwa bangsa-bangsa khususnya di Asia Pasifik perlu mempunyai "outward and forward looking" internal masyarakat dan bangsa, tetapi juga pandangan tersebut perlu dijalin dengan pandangan ke luar dan ke depan, karena masyarakat dan bangsa kita ádalah bagian dari statu masyarakat dunia yang semakin menyatu.

Dalam kaitannya dengan pendidikan, Jalal (2001:27) mengemukakan bahwa pendidikan nasional dewasa ini sedang dihadapkan pada empat krisis pokok, yang berkaitan dengan; (1) kuantiítas, (2) relevansi atau efisiensi eksternal, (3) elitisme, serta (4) manajemen pendidikannya. Lebih lanjut dikemukakan bahwa sedikitnya ada enam masalah pokok sistem pendidikan nasional; (1) menurunnya akhlak dan moral peserta didik, (2) pemerataan desempatan belajar,(3)masíhrendahnya efisiensi internal sistem pendidikan, (4) status kelembagaan, (5) manajemen pendidikan nasional yang tidak sejalan dengan pembangunan nasional, dan (6) sumber daya yang belum profesional. Belum lagi, dewasa ini tantangan dunia pendidikan asing di dalam negeri begitu menggurita seiiring dengan regulasi AFTA (Asian Free Trade Area) dimana semakin banyaknya lembaga pendidikan asing mulai dari sekolah dasar hingga perguruan tinggi dengan perangkat manajemen pendidikannya (kurikulum dan fasilitas pendidikan) yang 
berkualitas setiap saat dapat menghembaskan dunia pendidikan nasional manakala tidak kompetitif dan unggul ke jurang keterpurukan, terlebih bagi dunia pendidikan nasional yang berada di daerah-daerah yang kurang tersentuh oleh perkembangan akses informasi pendidikan yang memadai yang disinyalir masih lebih dari 53\% dari wilayah Indonesia.

Menghadapi hal tersebut, perlu dilakukan penataan terhadap sistem pendidikan secara menyeluruh(holistik), terutamaberkaitan dengan kualitas pendidikan, serta relevansinya dengan kebutuhan masyarakat dan dunia kerja. Pendidikan sebagaimana diungkapkan oleh Edward (2002:101) ádalah kehidupan, untuk itu kegiatan belajar harus dapat membekali peserta didik dengan kecakapan hidup (life skill atau life competency) yang sesuai dengan lingkungan kehidupan dan kebutuhan peserta didik. Pemecahan masalah secara reflektif sangat penting dalam kegiatan belajar yang dilakukan melalui kerjasama secara demokratis, berkesinambungan dan terencana secara matang. UNESCO (1994) mengemukakan dua prinsip pendidikan yang sangat relevan dengan Indonesian Nasional Educational Spirit (semangat pendidikan nasional Indonesia), pertama, pendidikan harus diletakkan pada empat pilar; yaitu relajar mengetahui (learning to know), relajar melakukan (learning to do), relajar hidup dalam kebersamaan (learning to live together), dan relajar menjadi diri sendiri (learning to be); kedua, belajar seumur hidup (life long learning). Kultur akademis yang demikian harus dikembangkan dalam pembangunan manusia Indonesia, karena pada akhirnya aspek kultural dari kehidupan manusia lebih penting dari pertumbuhan ekonomi. Dan itu hanya bisa dilakukan hanya dengan menjadikan pendidikan sebagai garda depan pembangunan manusia Indonesia yang lebih unggul dan kompetitif tanpa harus kehilangan jati dirinya serta moralitas kemanusiaannya (Suyanto dan Hisyam, 2003:54).

Dalam konteks itulah, melalui makalah yang sederhana namun cukup komprehensif ini penulis akan mengkaji salah satu aspek pendidikan yang memiliki urgensifitas dalam turut menentukan keberhasilan arah pendidikan nasional yaitu manajemen kurikulum melalui refleksi aplikasi manajemen kurikulum bagi pengembangan mutu SDM (khususnya out put pendidikan) di Madrasah Aliyah yang memiliki visi (wawasan) Internasional seperti beberapa MA di Indonesia (MAN Insan Cendekia, dan lain sebagainya). Refleksi ini berangkat dari pendekatan teoritis manajemen kurikulum dalam rangka menggali nilai-nilai kontributif yang dapat diaplikasikan 
dalam dunia pendidikan khususnya dalam rangka menemukan desain pengembangan manajemen kurikulum yang suitable dan qualified untuk dapat mensupport terwujudnya SDM Indonesia yang lebih unggul dalam mengarungi kompetisi global yang semakin kompetitif di masa yang akan datang.

\section{B. Pembahasan}

\section{Paradigma Manajemen Kuriklum sebagai Perangkat Obligatif Peningkatan Mutu Madrasah Aliyah}

Aplikasi manajemen dalam dunia pendidikan dewasa ini sudah bukan lagi hanya sekedar menjadi suatu tuntutan tetapi lebih dari itu sudah menjadi suatu kebutuhan yang mutlak adanya. Dalam konteks itu pula, sekolah-sekolah di Indonesia termasuk dalam hal ini di madrasah aliyah yang memiliki wawasan internasional seperti MAN Insan Cendekia. Salah satu aspek yang menjadi penekanan dalam bidang manajemen ádalah kurikulum. Dengan adanya manajemen kurikulum diharapkan, sekolah tidak hanya memiliki keunggulan di bidang desain program pendidikannya, tetapi lebih jauh lagi diharapkan dapat memberikan implikasi yang positif bagi pengembangan kualitas anak didik sebagai modal masa depan.

Dalam konteksyang lebih global, manajemen kurikulum diorientasikan sebagai paradigma upaya pembentukan SDM Indonesia yang lebih unggul dan kompetitif sebagaimana tuntutan masyarakat internasional atau yang lebih dikenal sebagai masyarakat abad 21 yang memiliki ciri-ciri yaitu; pertama, masyarakat teknologis (informasi sebagai sumber ekonomi, informasi dinikmati, dan informasi untuk pemenuhan kebutuhan pokok hidup). Kedua, masyarakat terbuka. Artinya madrasah atau sekolah harus akomodatif terhadap segala perkembangan yang terjadi, baik di lingkungan internal maupun eksternal lembaga tersebut. Ketiga, masyarakat madani (civil society) (Tilaar, 2001:98, Sukmadinata, 1988:17). Adapun paradigma manajemen pendidikan secara sederhana dapat dideskripsikan melalui skema berikut; 


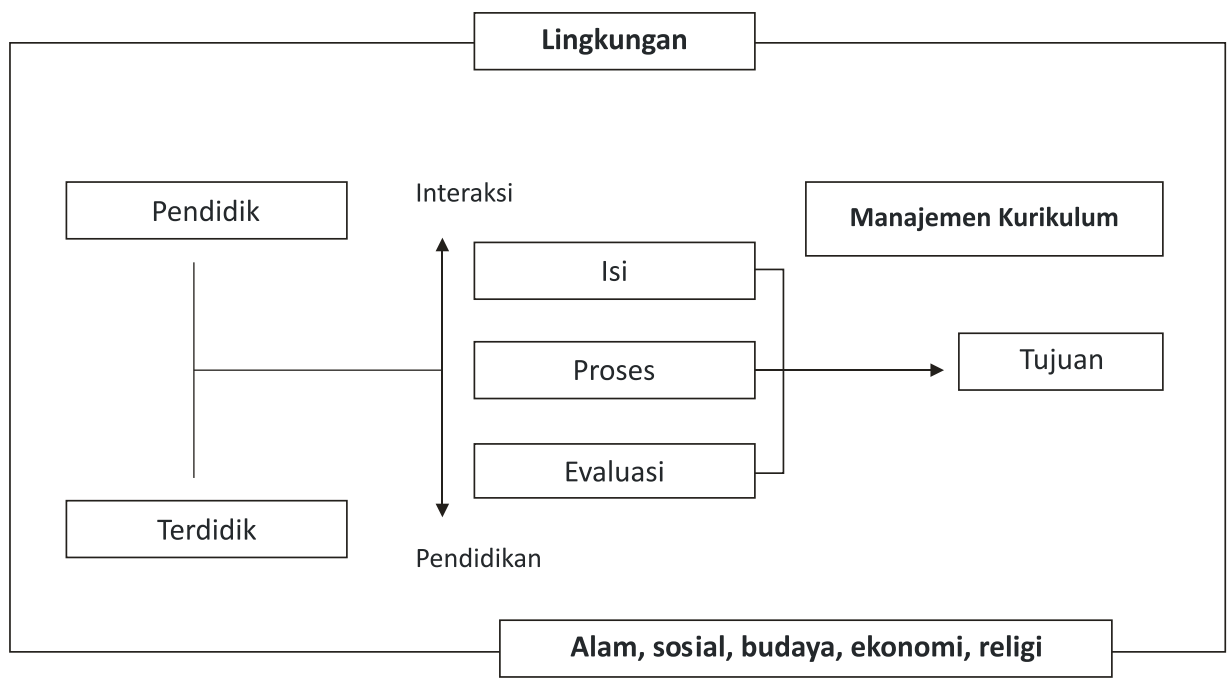

Skema tersebut menjelaskan secara jelas bahwa manajemen kurikulum meliputi dan dipengaruhi oleh berbagai komponen pendidikan serta lingkungan eksternalnya, mulai dari isi (materi), metode, tujuan, proses, guru, anak didik, lingkungan sosial, ekonomi, budaya dan religi (agama). Hal itu berarti bahwa paradigma manajemen kurikulum merupakan suatu kesatuan dari komponen pendidikan yang saling mensupport serta menentukan keberhasilan implementasi program pendidikan di sekolah. Dan itu juga berarti, sekolah atau madrasah haruslah selalu melihat dan mengikuti perkembangan masyarakat dalam berbagai aspeknya agar kebutuhan kurikulum sekolah sesuai dengan tuntutan masyarakat global maupun kebutuhan anak didik (potensi, minat dan bakatnya).

Dalam konteks pengelolaan kurikulum pada dasarnya manajemen kurikulum mengandung 4 sub bidang manajemen, sebagaimana dikonsepsikan oleh White (2000:37), yaitu; (1) manajemen sumber daya manusia (menyangkut pengelolaan SDM selaku pembuat dan pelaksana kurikulum serta pensukses aplikasinya bagi anak didik), (2) manejemen pembelajaran (menyangkut pengelolaan dan penggunaan metode, materi dan proses pembelajaran yang tepat dan sesuai dengan kebutuhan anak didik dan kebutuhan masyarakat), (3) manajemen fasilitas (menyangkut pengelolaan seluruh fasilitas pendidikan yang ada di sekolah) dan (4) manajemen penilaian (menyangkut upaya evaluasi terhadap performa 
hasil dari pelaksanaan kurikulum di sekolah). Ke 4 sub bidang manajemen tersebut bersifat integratif, artinya saling mensupport, mempengaruhi dan menentukan keberhasilan pelaksanaan kurikulum di sekolah. Secara sederhana keterkaitan ke 4 sub bidang tersebut dengan manajemen kurikulum dapat dideskripsikan melalui skema di bawah ini;

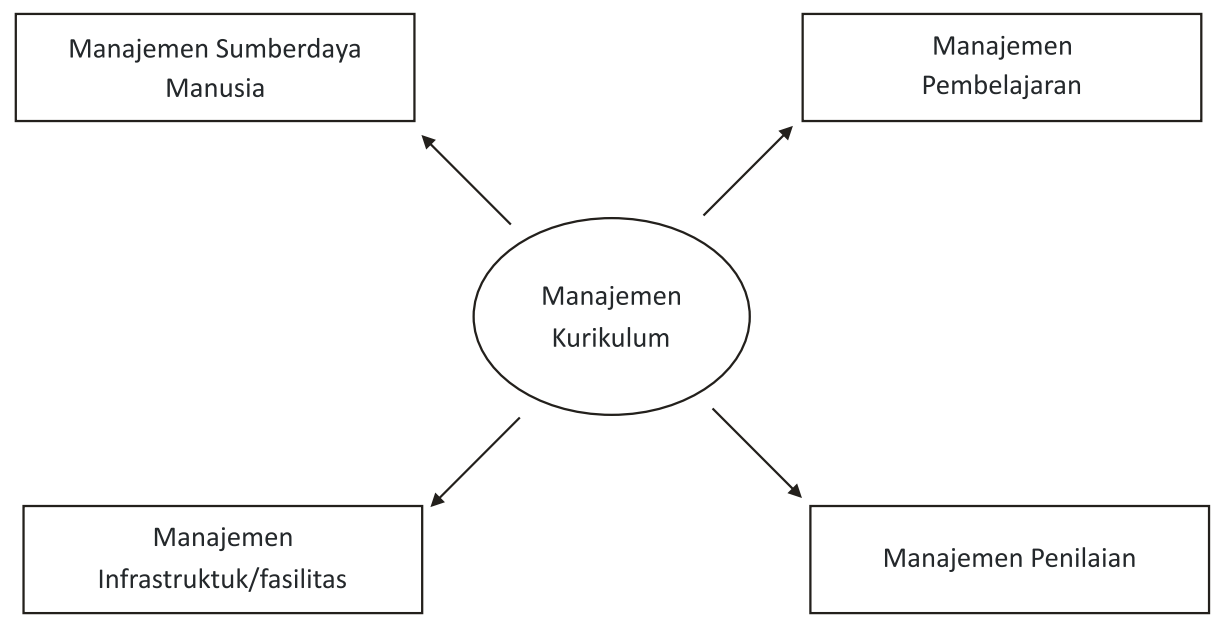

Gambar. Skema Sub Bidang Manajemen Kurikulum

\section{Prinsip-prinsip Kurikulum Bermutu dan Kompetitif bagi Sekolah/ Madrasah dan Upaya Pengembangannya}

Secara normatif, idealnya setiap sekolah memiliki acuan kurikulum standar yang dapat dijadikan sebagai pedoman dalam mendesain kurikulum pendidikan di sekolah khususnya dimadrasah yang lebih bermutu dan memiliki nilai kompetitif. Tanpa adanya standarisasi kurikulum, akan sulit bagi sebuah sekolah akan mampu menghasilkan program pendidikan yang bermutu di sekolah. Indikasi kebermutuan kurikulum itu menurut Print (1987) akan terlihat pada sejumlah hal; pertama, program pendidikan (pembelajaran dan kurikulum yang dihasilkan) sesuai dengan kebutuhan anak didik, guru dan masyarakat sebagai pengguna jasa pendidikan di sekolah. Kedua, kurikulum yang dirancang dapat diimplementasikan oleh para pendidikan dengan baik serta memiliki nilai balik yang positif (positif feedback) dimana anak didik dapat merespon, memahami dan 
mengaplikasikan materi yang disampaikan kepadanya. Ketiga, dengan desain kurikulum yang sedemikian masyarakat juga meresponnya secara positif ketika sekolah menghasilkan lulusan-lulusan yang bermutu dengan menggunakan jasa lulusannya (baik untuk di sektor publik maupun non publik) sehingga dapat dikatakan bahwa kurikulum tersebut memiliki nilai mutu dan kompetitif (having individual and social advantages). Di samping itu, nilai kebermutuan dan kompetitif menurut Mulyasa (2004:70) dari suatu kurikulum haruslah tetap mengacu kepada prinsipprinsip kurikulum yang didasarkan berbagai aspek, baik individual, sosial maupun kebangsaan dalam bahasa penulis disebut sebagai prinsip-prinsip kurikulum bermutu yang dapat dideskripsikan sebagai berikut;

a. Keimanan, nilai dan budi pekerti. Prinsip tersebut dianut dan dijunjung tinggi masyarakat dan berpengaruh terhadap sikap dan arti kehidupannya.

b. Penguatan integritas nasional.

c. Keseimbangan etika, logika, estetika, dan kinestetika.

d. Abad teknologi informasi dan pengetahuan.

e. Pengembangan keterampilan untuk hidup (lifeskill).

f. Belajar sepanjang hayat.

g. Berpusat pada anak dengan penilaian yang berkelanjutan dan komprehensif.

h. Pendekatan menyeluruh dan kemitraan.

\section{Strategi Peningkatan Manajemen Kurikulum dalam Pengembangan Mutu SDM Menuju Terwujudnya Lulusan Madrasah Aliyah Berwawasan Internasional}

Secara normatif, madrasah aliyah berwawasan internasional seperti halnya MAN Insan Cendekia Tangerang sebagai madrasah percontohan yang telah mampu mengantar anak didiknya ke gerbang kesuksesan seperti halnya studi ke luar negeri (Mesir, Sudan Maroko, Inggris, Australia dan Jepang) dengan prestise beasiswa juga memiliki orientasi pengembangan manajemen kurikulumnya dalam rangka memelihara kualitas dan 
kompetensi out put (lulusan) nya agar senantiasa sesuai dengan kebutuhan perkembangan zaman serta kompetisi internasional.

Dalam konteks aplikasi manajemen kurikulumnya, orientasi pada pengembangan 4 kompetensi fundamental, yaitu kompetensi akademik, kompetensi personal, kompetensi sosial dan kompetensi spiritual menjadi penekanan utama madrasah berwawasan internasional tersebut, baik ditujukan kepada performa guru maupun siswa khususnya secara seimbang dimana subtansi kompetensi itu mencakup sejumlah komponen sebagaimana ditegaskan oleh Skillbeck (1976:91-92) meliputi; (1) pengetahuan (knowledge); yaitu kesadaran dalam bidang kognitif, (2) pemahaman (understanding), yaitu kedalaman kognitif dan afektif yang dimiliki individu, (3) kemampuan (skill), yang merupakan sesuatu yang dimiliki individu untuk melakukan tugas atau pekerjaan yang dibebankan kepadanya, (4) nilai (values), yaitu suatu standar perilaku yang telah diyakini dan secara psikologis telah menyatu dalam diri seseorang, (5) sikap (attitude), yaitu menyangkut perasaan atau reaksi terhadap suatu rangsangan yang datang dari luar, serta (6) minat yang menyangkut kecenderungan seseorang untuk melakukan sesuatu perbuatan.

Upaya pencapaian keseimbangan kompetensi itu memang mutlak dilakukan, itu karena madrasah aliyah tersebut merupakan miniatur lembaga pendidikan Islam yang berupaya mewujudkan insan-insan muslim yang kaffah, yang tidak hanya memiliki kemampuan di bidang ilmu pengetahuan sebagai prasyarat utama persaingan global, tetapi juga memiliki kepekaan sosial, rasa kemanusiaan serta kepribadian religius yang bersendikan kepada moralitas nilai-nilai agama. Hal ini senada dengan apa yang ditegaskan oleh Thomas (1985:7) bahwa untuk menghadapi kompetisi global yang syarat akan arus negatif globalisasi, tidak cukup bagi seseorang hanya dengan memiliki modal sosial berupa penguasaan ilmu pengetahuan yang memadai an sich, tetapi lebih dari itu, ia juga harus memiliki rasa kemanusiaan dan moralitas yang tinggi agar mampu mengantisipasi ekses-ekses negatif tersebut untuk tidak terjerumus dalam lembah kenistaan, serta memiliki rasa kepercayaan diri yang kuat, atau meminjam bahasa Alfin Tofler, agar anak didik tidak mengalami culture shock akan intensitas kompetisi yang begitu tinggi dan kuat.

Dalam konteks pencapaian keseimbangan itu, madrasah aliyah 
berwawasan Internasional pada aspek kurikulumnya berupaya menyeimbangkan kebutuhan antara materi umum dan agama serta ditunjang oleh sejumlah materi keterampilan ekstrakulikuler seperti otomotif, komputer, study club for forengh language, dan lain sebagainya. Sedangkan pada aspek metode pembelajarannya diupayakan keaktifan siswa secara penuh dimana siswa diorientasikan sebagai aktor utama kesuksesan pembelajaran (student centered learning for the success) di sekolah, seperti halnya; praktek bahasa sehari-hari, kontinyuitas program pengembangan bahasa melalui pidato harian, lomba, mendatangkan native speaker, serta praktek keterampilan, studi banding dan lain sebagainya.

Ada sejumlah strategi peningkatan manajemen kurikulum dalam rangka pengembangan mutu SDM yang unggul dan kompetitif yang dapat diaplikasikan oleh madrasah aliyah berwawasan internasional yang penting dan layak untuk diapresiasikan sebagai bentuk desain pengelolaan kurikulum di sekolah/madrasah;

\section{1). Strategi berdasarkan pendekatan sistem pengelolaan manajemen kurikulum}

Dilihat dari pengelolaannya, manajemen kurikulum dibedakan antara sistem pengelolaan yang terpusat (sentralisasi), dan tersebar (desentralisasi). Kurikulum pendidikan dasar dan menengah tahun 1968 dan 1975 bersifat sentralisasi, hanya ada satu kurikulum untuk satu jenis pendidikan di seluruh Indonesia. Kurikulum ini bersifat nasional, seragam, dikembangkan oleh tim pusat, guru-guru hanya berperan sebagai pelaksana di sekolah, yakni menjabarkan rencana tahunan, caturwulan dan satuan pelajaran tiap pelajaran. Dalam kurikulum 1984 telah ada muatan lokal yang disisipkan pada berbagai bidang studi yang sesuai, dan hal ini lebih diintensifkan lagi pelaksanaannya dalam kurikulum 1994. Dalam kurikulum 1994 muatan lokal tidak lagi disisipkan pada setiap bidang studi, tapi menggunakan pendekatan monolitik berupa bidang studi, baik bidang studi wajib maupun pilihan.

Dengan adanya kebijakan otonomi daerah, kemungkinan muatan lokalnya akan lebih besar, modelnya lebih beragam dan sistemnya tidak terpusat lagi, sehingga pengelolaannya menjadi desentralisasi. Idealnya perimbangan muatan nasional dengan daerah antara 25\% - 40\% nasional 
dan 60\%-75\% daerah. Dengan bobot muatan daerah / lokal yang lebih besar berarti pengembangan kurikulum lebih banyak dilakukan oleh tim pengembang yang terdiri atas para ahli dan guru-guru di daerah. Kurikulum juga akan lebih banyak diwarnai oleh unggulan daerah, baik kekayaan, perkembangan muapun kebutuhan daerah. Model kurikulumnya akan beragam sesuai dengan tujuan, fungsi dan isi program pendidikan. Pengembangan kurikulum menjadi lebih berbasis daerah atau kewilayahan. Kurikulum yang demikian ada yang menyebutnya kurikulum berbasis masyarakat, ada juga yang menyebutnya kurikulum berbasis sekolah.

\section{2). Strategi berdasarkan pendekatan fokus sasaran manajemen kurikulum}

Berdasarkan fokus sasaran, peningkatan manajemen kurikulum dibedakan antara pendekatan yang mengutamakan penguasaan ilmu pengetahuan, penguasaan kemampuan standar, penguasaan kompetensi, pembentukan pribadi, dan penguasaan kemampuan memecahkan masalah sosialkemasyarakatan.Pertama, pendekatan penguasaanilmupengetahuan, merupakan model pengembangan kurikulum yang menekankan pada isi atau materi, berupa pengatahuan, pemahaman, aplikasi, analisis, sintesis, dan evaluasi yang diambil dari bidang-bidang ilmu pengetahuan.

Kedua, pendekatan kemampuan standar, yang menekankan pada penguasaan kemampuan potensial yang dimiliki peserta didik sesuai dengan tahap-tahap perkembangannya. Ketiga, pendekatan pembentukan pribadi, menekankan pada pengembangan atau pembentukan aspek-aspek kepribadian secara utuh, baik pengetahuan, keterampilan, maupun nilai dan sikap. Dalam pelaksanaannya para pengembang kurikulum ini banyak memberikan perhatian terhadap aspek-aspek sosial-emosional. Keempat, pendekatan pemecahan masalah (problem solving) kemasyarakatan, diarahkan pada terciptanya masyarakat yang lebih baik. Pengembangan kurikulumnya menekankan pada pengembangan kemampuan memecahkan masalah-masalah penting dan mendesak yang ada di masyarakat, baik masyarakat sekitar maupun yang lebih jauh. Pendekatan ini banyak dilakukan dalam manajemen kurikulum pendidikan luar sekolah. Kelima, pendekatan kompetensi, merupakan model peningkatan manajemen kurikulum yang menekankan pada pemahaman, kemampuan atau 
kompetensi tertentu di sekolah, yang berkaitan dengan pekerjaan yang ada di masyarakat.

\section{3). Strategi berdasarkan pendekatan kompetensi manajemen kurikulum}

Pendekatan kompetensi merupakan pendekatan peningkatan manajemen kurikulum yang memfokuskan pada penguasaan kompetensi tertentu berdasarkan tahap-tahap perkembangan peserta didik. Peserta didik berada dalam proses perkembangan yang berkelanjutan dari seluruh aspek kepribadian, sebagai pemekaran terhadap potensi-potensi bawaan sesuai dengan kesempatan belajar yang ada dan diberikan oleh lingkungan.

Untuk kepentingan kesuksesan strategi dan efektivitas pelaksanaan manajemen kurikulum, pimpinan sekolah (utamanya kepala sekolah) haruslah mampu memobilisasi sumber daya sekolah yang berkaitan dengan beberapa hal penting (Mulyasa, 2004:183); pertama, perencanaan dan evaluasi program sekolah. Sekolah diberi kewenangan untuk melakukan perencanaan sesuai dengan kebutuhannya (school-based plan), seperti kebutuhan untuk meningkatkan mutu sekolah. Kedua, pengembangan kurikulum berbasis kompetensi guna mensupport secara maksiman pencapaian kebutuhan lifeskill bagi anak didik di sekolah nantinya dimana memberikan kewenangan kepada daerah dan sekolah untuk mengidentifikasi kompetensi dan mengembangkan silabus sesuai dengan keutuhan daerah, kebutuhan dan karakteristik peserta didik. Ketiga, pemgembangan pembelajaran. Proses pembelajaran merupakan interaksi edukatif antara peserta didik dengan lingkungan sekolah. Dalam hal ini sekolah diberi kebebasan untuk memilih strategi, metode, dan teknikteknik pembelajaran yang paling efektif, sesuai dengan karakteristik mata pelajaran, karakteristik siswa, karakteristik guru, dan kondisi nyata sumber daya yang tersedia di sekolah.

Keempat, pengelolaan ketenagaan. Pengelolaan ketenagaan, mulai dari analisis kebutuhan, perencanaan, rekrutmen, pengembangan, reward dan sangsi (punishment), hubungan kerja, sampai evaluasi kinerja tenaga kerja sekolah (guru, tenaga administrasi, dan laboran) dapat dilakukan oleh sekolah, kecuali yang menyangkut penggajian atau upah, dan rekrutmen guru pegawai negeri, yang sampai saat ini ditangani oleh birokrasi di 
atasnya. Kelima, pengelolaan sarana dan sumber belajar. Pengelolaan sarana dan sumber belajar sudah sewajarnya dilakukan oleh sekolah, mulai dari pengadaan, pemeliharaan dan perbaikan hingga sampai pengembangan. Hal ini didasari oleh kenyataan bahwa sekoahlah yang paling mengetahui kebutuhan sarana dan sumber belajar, baik kecukupan, kesesuaian, maupun kemutakhirannya, terutama sumber-sumber belajar yang dirancang (by design) secara khusus untuk kepentingan kesuksesan pembelajaran anak didik.

Keenam, pengelolaan keuangan. Pengelolaan keuangan terutama pengalokasian atau penggunaan uang sudah sepantasnya dilakukan oleh sekolah. Hal ini juga didasari oleh kenyataan bahwa sekolahlah yang paling memahami kebutuhannya, sehingga desentralisasi pengalokasian dan penggunaan uang dilimpahkan ke sekolah. Ketujuh, pelayanan siswa. Pelayanan siswa mulai dari penerimaan siswa baru, pengembangan, pembinaan, pembimbingan, penempatan untuk melanjutkan sekolah atau untuk memasuki dunia kerja, sampai pada pengurusan alumni, sepenuhnya merupakan kewenangan sekolah yang menuntut kemampuan kepala sekolah untuk mengembangkannya.

Kedelapan, hubungan sekolah dengan masyarakat. Hakekat hubungan sekolah dengan masyarakat adalah untuk meningkatkan keterlibatan, kepedulian, kepemilikan, dan dukungan dari masyarakat terutama dukungan moral dan finansial. Kesembilan, penciptaan iklim sekolah. Kesembilan, iklim sekolah (fisik dan non fisik) yang kondusif-akademik merupakan prasyarat bagi terselenggaranya implementasi manajemen kurikulum secara lebih efektif. Lingkungan sekolah yang aman dan tertib, optimisme dan harapan yang tinggi dari warga sekolah, kesehatan sekolah, dan kegiatan-kegiatan yang terpusat pada siswa (student-centered activities) merupakan iklim sekolah yang dapat menumbuhkan semangat belajar siswa.

\section{Kesimpulan}

1. Orientasi atau tujuan penting yang ingin dicapai dari manajemen kurikulum dalam konteks pengembangan mutu SDM terutama out put nya di madrasah aliyah berwawasan internasional dikembangkan 
untuk mencapai 4 kompetensi utama; kompetensi akademik, personal, sosial dan spiritual yang mencakup sejumlah elemen kompetensi yang meliputi; (1) pengetahuan (knowledge); yaiu kesadaran dalam bidang kognitif, (2) pemahaman (understanding), yaitu kedalaman kognitif dan afektif yang dimiliki individu, (3) kemampuan (skill), yang merupakan sesuatu yang dimiliki individu untuk melakukan tugas atau pekerjaan yang dibebankan kepadanya, (4) nilai (values), yaitu suatu standar perilaku yang telah diyakini dan secara psikologis telah menyatu dalam diri seseorang, (5) sikap (attitude), yaitu menyangkut perasaan atau reaksi terhadap suatu rangsangan yang datang dari luar, serta (6) minat yang menyangkut kecenderungan seseorang untuk melakukan sesuatu perbuatan.

2. Untuk meningkatkan manajemen kurikulum dalam rangka pengembangan mutu SDM terutama lulusannya, Madrasah Aliyah berwawasan internasional mengaplikasikan strategi yang tepat agar seluruh potensi SDM yang ada di sekolah dapat berkembang secara optimal dan menghasilkan out put yang unggul dan kompetitif. Strategi tersebut antara lain; pertama, strategi berdasarkan pendekatan sistem pengelolaan dimana harus ditekankan pada pengelolaan kurikulum secara mandiri, kreatif dan inovatif oleh madrasah sesuai dengan semangat otonomi (spirit of otonomy). Kedua, strategi berdasarkan pendekatan fokus sasaran yang meliputi aspek penguasaan ilmu pengetahuan, penguasaan kemampuan standar, penguasaan kompetensi, pembentukan pribadi, dan penguasaan kemampuan memecahkan masalah sosial kemasyarakatan anak didik. Ketiga, strategi berdasarkan pendekatan kompetensi memfokuskan pada penguasaan kompetensi tertentu berdasarkan tahap-tahap perkembangan peserta didik. Keberhasilan strategi itu harus didukung pula oleh kemampuan pimpinan sekolah untuk memobilisasi potensi sumber daya yang ada di sekolah

\section{DAFTAR PUSTAKA}

Edward, Philip. Management and Curriculum in Education: Concept and Practice. Prenhall Ltd: New York. 2002. 
Jalal, Fasli (editor), dkk. Reformasi Pendidikan dalam Konteks Otonomi Daerah. Adicita\& Depdiknas: Yogyakarta. 2001.

Mulyasa.E. Kurikulum Berbasis Kompetensi: Konsep, Karakteristik dan Implementasi. Rosdakarya: Bandung. 2004.

. Pedoman Pemahaman dan Penerapan Kurikulum Muatan Kurikulum di Sekolah Dasar. Geger Sunten: Bandung. 1999.

Maslow, A. Motivation and Personality. Harper and Row: New York. 1970.

Print, Murray. Curriculum Development and Design. Allen and Unwin: Sidney. 1987.

Sukmadinata, Nana Syaodih. Prinsip dan Landasan Pengembangan Kurikulum. P2LPTK Depdikbud: Jakarta. 1988.

Skillbeck, Malcolm. School Based Curriculum Development and Teacher Education. OECD: Mimeograph. 1976.

Suyanto dan Djihad Hisyam. Refleksi dan Reformasi Pendidikan di Indonesia Memasuki Milenium III. Adicita: Yogyakarta. 2003.

Thomas, J. Alan. The Productive School: A System Analisys Approach to Educational Administration. Chichago University. 1985.

Tilaar, H.A.R. Manajemen Pendidikan Nasional: Kajian Pendidikan Masa Depan. Remaja Rosdakarya: Bandung. 2001.

White, John. International Curriculum and Its Great Purpose. Educational Studies: Kogan Page. 2000. 